\title{
Assessment of Ficus thonningii tree production and utilization for livestock feed by smallholder farmers in northwestern Ethiopia
}

\author{
Bimrew Asmare* and Yeshambel Mekuriaw
}

\begin{abstract}
Background: An assessment on the management practices and uses of Ficus thonningii tree by smallholder farmers' was carried from December 2014 to March 2015 to evaluate the status of tree management, utilization as livestock feed and identify major production and utilization constraints. Three districts were purposely selected based on abundance of the tree from northwestern Ethiopia, and from each district, three peasant associations (smallest administrative unit) were selected purposely based on the abundance of $F$. thonningii availability and farmers' utilization practices. The methodology of the study encompasses questionnaire, group discussion, key informant interview and secondary data sources. Descriptive statistics and linear regression were employed to present the quantitative and qualitative variables obtained from the survey.

Results: The result indicated in all districts, livestock feed shortage during dry season was a critical problem. The ownership of $F$. thonningii tree indicated nonsignificant $(P>0.05)$ difference among the study districts. The types of livestock species reported feeding F. thonningii were cattle (54.2\%), sheep (24.1\%) and goats (21.7\%) in all study districts. Among the parts of the tree used as feed, leaves in fresh form were used as dry season supplement to the livestock. The majority of respondents in the study districts reported to have accustomed practicing feeding $F$. thonningii leaves in the fresh from, followed by wilting and both fresh and wilting. Of the constraints of farmers in the study districts in using F. thonningii as feed for livestock were lack of training (51\%), followed by land shortage (31\%) and labor scarcity (18\%).

Conclusions: This preliminary assessment indicated that the tree has valuable benefit to mitigate critical livestock feed scarcity in the dry season; farmers do have many constraints in its fullest utilization. Hence, to exploit the potential of F. thonningii as livestock fodder in northwestern Ethiopia, smallholder farmers should get training on production and utilization of the fodder tree.
\end{abstract}

Keywords: Ficus thonningii, Fresh leaves, Livestock, Mitigation, Northwestern Ethiopia

\section{Introduction}

Livestock production is an integral part of the livelihood of the household level and contributes significantly to the national economy of Ethiopia [1, 2]. However, contribution of the sub-sector in the country's economy remains below its potential due to low productivity of animals than the regional and continental average. Low

\footnotetext{
*Correspondence: limasm2009@gmail.com
}

Department of Animal Production and Technology, School of Animal

Science and Veterinary Medicine, Bahir Dar University, P.O. Box 5501, Bahir Dar, Ethiopia productivity of animals stems from poor feed resources available to all classes of animals which lead to under exploitation of the sub-sector [3]. According to [4], highlands have high human population density that has led to intensive crop production at the expense of conversion of grazing land to crop land. Therefore, there is a need, to seek for new ways of improving the nutritive value and utilization of poor quality roughages so as to improve efficiency of utilization under dry conditions occurring in the tropics. Among these options, supplementation of available indigenous browse trees and treatment of crop 
residues with available technology in the tropics are of paramount importance. Multipurpose fodder trees, such as $F$. thonningii tree, offer a good opportunity to integrate livestock and crop production while optimizing the returns to input in Ethiopia [5]. F. thonningii tree is widely distributed in northwestern Ethiopia used as dry season feed supplement for ruminant livestock.

In comparative study of $F$. thonningii and Mango indica leaves fed [6] for rabbits, the leaves of $F$. thonningii had significantly higher average daily weight gain and feed/ gain efficiency, and both of these species have feeding value as fodder for rabbits making survival possible to them during critical periods in the dry seasons. Ficus thonningii is found naturally as dry season fodder to be used by smallholder farmers for ruminant livestock. In addition, some farmers also practice planting of $F$. thonningii in the backyard and farmland as a mitigation strategy for dry season feed shortage. However, there are no studies conducted on its role as feed supplement in ruminant nutrition especially in integration of multipurpose trees with crop livestock systems in Ethiopia. The objective of this research was to assess farmers indigenous practices of $F$. thonningii production, management and utilization for livestock feed in northwestern Ethiopia.

\section{Materials and methods Study areas}

The assessment was conducted in three districts, namely Bahir Dar Zuria, Farta and South Achefer in northwestern Ethiopia from 2014 to 2015.

\section{Bahir Dar Zuria district}

Bahir Dar Zuria district is approximately $1283.6 \mathrm{~km}$ and contains 32 kebeles, from which three kebeles were selected for this study. The District is bounded in the east by South Gonder Zone, in the west by Mecha and Achefer Districts and by Lake Tana, Yelimana Densa District in the north and south, respectively. The landholding of the farmers is small and highly fragmented as a result of increasing population pressure from time to time. Land is the main input for agriculture.

\section{Farta district}

Farta district is located at $660 \mathrm{~km}$ northwest of Addis Ababa and $102 \mathrm{~km}$ to the west of Bahir Dar and lies between $11^{\circ} 32^{\prime}$ to $12^{\circ} 03^{\prime} \mathrm{N}$ latitude and $37^{\circ} 31^{\prime}$ to $38^{\circ} 43^{\prime} \mathrm{E}$ longitude. Farta district is bordered to the south by Este, to the west by Fogera, to the north by Ebenat and to the east by Lay Gayint. Altitudes of the district were 2701 $\mathrm{m}$ above sea level. As reports indicate that in terms of topography, $45 \%$ of the total area is gentle slope and flat and steep slope lands are for $29 \%$ and $26 \%$, respectively.
The mean maximum temperature of Farta district is $21^{\circ} \mathrm{C}$ from February to May. The mean minimum temperature is $9.6{ }^{\circ} \mathrm{C}$ from June to January, while the mean annual temperature of the District is $15.5^{\circ} \mathrm{C}$. The rainfall pattern in the District is uni-modal. According to the meteorological report, the mean annual rainfall is $1570 \mathrm{~mm}$. Rain usually starts in mid March, but the effective rainy season is from May to mid September with mean precipitation of $1950 \mathrm{~mm}$.

\section{South Achefer district}

South Achefer district, one of the thirteen districts as found in west Gojjam Administrative Zone, is located $60 \mathrm{~km}$ southwest of Bahir Dar town, the capital of Amhara Region. It borders North Achefer to the North, Awi zone to the south and west and Mecha district to the east. It is subdivided into 18 rural and 2 urban kebele administrations (the lowest level in the hierarchy of government administrative system). About $87 \%$ of the district has a temperate climate, and the remaining $13 \%$ has cold climatic conditions. The mean annual rainfall ranges from 1450 to $1594 \mathrm{~mm}$.

\section{Data collection and statistical analysis}

A cross-sectional study design was used for this investigation. The primary data were collected through interview using semi-structure questionnaire and group discussion pertaining to socioeconomic characteristics: demographic nature, size of household, education, ethnic and religion, age, gender, credit, extension service, while the secondary data from concerned institutions. Two Kebeles from each district and 30 households from each selected Kebele were randomly selected for purpose of this study. In addition, land possession, livestock number, availability and distribution of fig tree and utilization strategies was studied. Livestock holding per household was converted to tropical livestock unit using the conversion factors [7]. A focus group interview was held in each Kebele with a group of six individuals consisting of the elderly and residing in the area for long time. The discussion was conducted in public areas on key topics of management, nutrition and watering, and health care. Due to occasional biases by questionnaire respondents, some extra complementary procedures to cross-check and validate findings include three key informant interviews used in each Kebele, which were selected based on the experience of $F$. thonningii utilization. Also problems prevailing in fig tree utilization, storage and feeding and related issues were assessed using semi-structured questionnaire. Information about feed sources, prices and access was collected. Problems related to feed shortage in terms 
of quantity and quality visa vis mitigation strategies were collected in each study site.

The data were complemented with information obtained from key informants and secondary data derived from regional and zonal office of agriculture. The collected data were systematically coded and analyzed with SPSS 20. Descriptive statistics and linear regression were used for data analysis calculated to present the quantitative and qualitative variables obtained from the survey.

\section{Results and discussion}

\section{Household characteristics of respondents}

The mean age and educational characteristic of household heads are presented in Table 1. In the study districts, the mean age of household heads was between 47 and 53 years. The age structure of household heads agrees with the reports of $[8,9]$, whose report for the household age was 44.9 in Burie Zuria district of northwestern Ethiopia. The sex of household heads in the two districts was $100 \%$ male which is different from [10] who stated that more than $80 \%$ of households were male, while the rest were female respondents.

The sex of household heads was the same in all the three districts in which male sex was common which might be associated with the fact that male headed households have more access to agricultural works and feeding of livestock. As it is a proven fact in other disciplines, females have more access to household issues like health care and family planning matters. The family size in the current study was 6.8 . This is comparable to reports of [11] who reported 6.3 family members in the household. The mean family size of respondents is comparable to earlier reports in northwestern Ethiopia [12, 13] in different agroecological conditions of Ethiopia.

The educational characteristics of respondents indicated that in Bahir Dar Zuria districts, the majority of household heads (57.14) were illiterate followed by read and write (42.86\%). In Farta and South Achefer, relatively higher numbers of respondents were literate in which

\begin{tabular}{|c|c|c|c|c|}
\hline $\begin{array}{l}\text { Education level } \\
\text { of } \mathrm{HH}\end{array}$ & BZD $(N=60)$ & $\mathrm{FD}(N=60)$ & $\operatorname{SAD}(N=60)$ & Mean \\
\hline |lliterate (\%) & 57.14 & 33.33 & 26.32 & 38.9 \\
\hline Read and write (\%) & 42.86 & 50.00 & 57.89 & 50.3 \\
\hline $\begin{array}{l}\text { Elementary school } \\
\text { (\%) }\end{array}$ & - & 16.67 & 15.79 & 10.8 \\
\hline Mean age of $\mathrm{HH}$ & 53 & 49 & 48 & 50.0 \\
\hline $\begin{array}{l}\text { Mean family size } \\
(\mathrm{N})\end{array}$ & 7.29 & 6 & 7.1 & 6.8 \\
\hline
\end{tabular}

$N$ Number, BZD Bahir Dar Zuria district, FD Farta district, SAD South Achefer district, $H H$ household head read and write were $50 \%$ and 57.89 , respectively. The overall result of educational characteristics higher than educational characteristics reported by [14] where $31 \%$ of the respondents illiterate, $28 \%$ are able to read and write, $2.5 \%$ religious education, $21.3 \%$ attended primary school, and $17.2 \%$ completed secondary school North Gonder Zone, Ethiopia. Higher literate class has advantage on the good acceptance of technologies like trainings, improved agricultural technologies and adopting them for better live improvement. It has been stated that low level of education of the households can have an influence on the transfer of agricultural technologies and their participation in development [15].

Landholding and ownership characteristics of respondents The landholding and ownership characteristic of respondents are shown in Table 2. The average landholding of respondents was between 1.15 and $1.52 \mathrm{ha}$. The current land size per household of respondents is higher than [16] who reported that landholding of respondents that ranges from 0.25 to 0.75 ha per person in the study districts. The result of the current study is lower than reports of $[17,18]$ who reported 2.2 ha in the same area. Overall, the landholding of household heads in the three districts is lower than the national average landholding size of 1.6 ha reported by [19] for Ethiopia.

The result of this study indicated that much of the land owned by the respondents was allocated to crop farming in consistent with that of $[8,9]$ in Dandi district of Ormoiya Region indicating that land allocation for grazing is minimal in all study districts. Total landholding of the study districts is very limited as compared to previous studies in Ethiopia [20] who indicated that

Table 2 Land use and farming system characteristics of respondents $(N=180)$

\begin{tabular}{llll}
\hline $\begin{array}{l}\text { Household } \\
\text { characteristics }\end{array}$ & BZD $(\mathbf{N = 6 0 )}$ & FD $(\boldsymbol{N = 6 0 )}$ & SAD $(\boldsymbol{N = 9 0 )}$ \\
\hline $\begin{array}{l}\text { Mean total landholding/ } \\
\text { HH (ha) }\end{array}$ & 1.52 & 1.15 & 1.66 \\
Mean crop land (ha) & 1.41 & 1.04 & 0.98 \\
Mean grazing land (ha) & 0.21 & 0.10 & 0.15 \\
Mean fallow land (ha) & 0.13 & 0.02 & 0.03 \\
Grazing land ownership & & & \\
Private (\%) & 15 & 66.67 & 85 \\
Shared (\%) & 75 & - & - \\
Shared and private (\%) & 10 & 33.33 & 15 \\
Crop land ownership & & & \\
Private (\%) & 60 & 100 & 75 \\
Private and rented (\%) & 40 & - & 25 \\
\hline
\end{tabular}

Ha Hectare, N number, BZD Bahir Dar Zuria district, FD Farta district, SAD South Achefer district 
a typical smallholder farm with 2.5 ha of land in the Ethiopian highlands of Ada district produces a total of approximately 6 tonnes of DM from crop residues. The discrepancy between the current finding and earlier reports might be due to the variation in the locations of study and due to time gap that the grazing area per household is dwindling. The majority of respondents in Farta and north Achefer (66.67 and 85\%) do have private grazing land, while only few (15\%) have this type of grazing land in Bahir Dar Zuria district. Distance of farm land from the homestead is an important factor in management of time and productivity of the house hold. The average farthest and shortest in walking of the study districts was 35.83 and $2.85 \mathrm{~min}$, respectively. The relatively shorter walking distance observed in this study reduces the cost of walking energy of grazing animals in the study areas [21].

\section{Livestock holding and purpose}

The livestock holding of study districts is shown in Table 3. The most important livestock are cattle followed by sheep in all study districts. The total livestock holding of districts was higher than reports of $[8,9$, 15]. This may be due to the fact that cattle are important for traction, milk and means of cash income. Cattle are the dominant livestock in all study districts as they

Table 3 Mean livestock holding (TLU) and chicken characteristics of respondents $(N=180)$

\begin{tabular}{lllll}
\hline Livestock & BZD $(\boldsymbol{N = 6 0 )}$ & FD $(\boldsymbol{N = 6 0 )}$ & SAD $(\boldsymbol{N = 6 0 )}$ & Mean \pm SD \\
\hline Cattle & 6.9 & 6.8 & 6.5 & $6.73 \pm 0.21$ \\
Sheep & 0.8 & 0.5 & 0.6 & $0.63 \pm 0.15$ \\
Donkey & 0.7 & 0.5 & 0.6 & $0.60+0.10$ \\
Mule & - & 1.2 & 0.8 & $0.67 \pm 0.61$ \\
Horse & 0.8 & 0.8 & 2.0 & $1.20 \pm 0.69$ \\
Chicken & 7.00 & 5.00 & 16.33 & $9.44 \pm 0.05$ \\
\hline
\end{tabular}

$N$ Number, BZD Bahir Dar Zuria district, FD Farta district, SAD South Achefer district are used primarily for draft power, traction, milk and meat as secondary interest. Cattle also have an important sociocultural role in the study area. The finding is in agreement with the results of $[8,9]$. Sheep are also very important component of the livestock production system in all study districts which may be due to their impertinence as immediate cash income for the family. The result agrees with earlier reports in northwestern Ethiopia [13] who reported that cattle are the dominant livestock in the study areas.

The purpose of livestock keeping in the study districts areas was the same that livestock were used for different socioeconomic purposes for the household including traction, food and cash income [21]. Cows are reared mainly for milk production, manure output and cash income, while oxen are kept primarily for draft power followed by cash income and reproduction. The purpose of small ruminants is primarily for cash income followed by meat production. Equine are kept mainly for draft power especially for pack animals. Chicken are primarily kept for meat production for household consumption followed by income generation. Purpose of livestock keeping in the study areas is similar to the reports in northwestern Ethiopia [22, 23] (Table 3).

\section{Feed resources and feeding}

The major feed resources during dry season in study districts are grazing $(59.25 \%)$ followed by crop residues $(41.25 \%)$ such as cereal straws. The supplements of grazers during dry season are indigenous fodder trees like $F$. thonningii, while in wet season, the major feed resources are grazing followed by cut forage and weeds. In other studies, under Ethiopian farming system condition, crop residues provided $40-50 \%$ of the annual livestock feed requirement [24]. In the central highlands of Ethiopia, in most intensively cultivated areas, crop residues and aftermath grazing account for above $60-70 \%$ of the basal diet [25]. The quantities of different crop residues produced depend on the total area cultivated, the access of the season's rainfall, crop species as well as other inputs

Table 4 Socioeconomic characterstics of Ficus thonningii tree producer respondents

\begin{tabular}{|c|c|c|c|c|c|c|}
\hline \multirow[t]{2}{*}{ Variables } & \multicolumn{2}{|l|}{ BZD } & \multicolumn{2}{|l|}{ FD } & \multicolumn{2}{|l|}{ SAD } \\
\hline & $P$ value & SL & $P$ value & SL & $P$ value & SL \\
\hline Age of HH & 0.07 & Ns & 0.167 & Ns & 0.686 & Ns \\
\hline Education of $\mathrm{HH}$ & 0.23 & Ns & 0.111 & Ns & 0.837 & Ns \\
\hline Family size & 0.42 & Ns & 0.073 & Ns & 0.564 & Ns \\
\hline Landholding of HH & 0.58 & Ns & 0.151 & Ns & 0.958 & Ns \\
\hline Number of Livestock per HH & 0.66 & Ns & 0.051 & Ns & 0.480 & Ns \\
\hline
\end{tabular}

HH Household, BZD Bahir Dar Zuria district, FD Farta district, NAD South Achefer districts, SL significant level 
such as fertilizers. Livestock feeding calendar is an essential livestock management practice to use the available feed resources efficiently and to supply the livestock with high-quality and high-quantity feeds and to overcome feed shortage. Livestock feeding calendar varies depending on availability of the feed resources in the different months of the year [26].

\section{Feeding practice and supplementing animals}

The grazing practices of study districts were similar with all respondents (100\%) following partial grazing, while 90\% of the respondents in Farta district practiced partial grazing and about $10 \%$ practiced free grazing. In South Achefer, $60 \%$ of the respondents practiced partial grazing followed by free grazing (40\%). In Bahir Dar Zuria and South Achefer districts, all (100\%) respondents provided supplements during dry season for their animals, while in Farta district the majority (60\%) of respondents provided supplementation. The type of supplement in study districts was obtained from purchasing and home by-products. The bought supplements were noug seed cake, wheat bran and homemade by-products like local breweries by-products (Atela). The livestock feeds and feeding strategies in this study area are in agreement with the reports $[13,22]$ in northwestern Ethiopia.

The major ruminant feed resources during dry season in all districts were crop residues, grazing, leaves and twigs of fodder trees, by-product supplements. In wet season ruminant animals mainly depend on grazing pasture and supplementation with farm weeds and crop residues. In all of the districts, livestock producers faced feed shortage especially from June to September. Farmers followed different strategies to tackle feed shortage among which buying feeds (50\%), selling livestock (25\%) and both $(25 \%)$ were the main methods. The status of livestock ownership is decreasing these days mainly due to prevailing feed scarcity in the areas. The major crop residues in Bahir Dar Zuria district were millet, teff and maize. In the district, the purpose of crop residues was for animal feed (61.8\%) followed by fuel (21.2\%) and construction (17\%). The livestock feeding strategy in Bahir Dar Zuria district was partial grazing and home feeding practice. In the district, all respondents (100\%) practiced supplementation during dry season. In South Achefer district, $27.8 \%$ of the respondents practiced free grazing, while about $72.2 \%$ practiced partial grazing and home feeding such as tethering and feeding straws at homestead area. The types of supplements used by farmers were noug seed cake and wheat bran. Similarly, in South Achefer district, the major supplements for livestock were breweries by-products and leaves and twigs of multipurpose trees.

\section{Feed shortage and mitigation strategies}

In the three study districts, all respondents (100\%) reported that they faced livestock feed shortage irrespective of wet and dry seasons. The months of feed shortage were different in the study districts which are related to the agroecology and farming systems. In Bahir Dar Zuria district, the majority of respondents (85.71\%) faced feed shortage from June to September followed by May to June (14.29\%). In the three study districts, all respondents $(100 \%)$ faced feed shortage from June to September, while respondents (100\%) faced feed shortage from May to June. Feed shortage tackling strategies of respondents included use of crop residues, buying feeds and decreasing the number of livestock. The results indicated that farmers use different strategies to overcome feed shortage as stated by Abebe et al. [27] and Adugna and Said [28].

\section{Ficus thonningii production and utilization}

According to all respondents (100\%), the fodder $F$. thonningii was one of naturally available feed source for dry season supplement and should be planted as backyard forage. The introduction of improved forage species for ruminant can promote the sustainability of the cropping system. In addition to their feeding value which is well developed, improved forages particularly legumes can make important contribution to erosion by providing cover and to increase soil fertility by enhancing nutrient and organic matter level [29]. Shrubs and fodder trees play a significant role in livestock production in all agroecological zones of tropical Africa. The importance is, however, the increase in areas that are arid. Fodder tree forages are commonly browsed directly on trees or other lopping by livestock herders. They are also offered as cut-and carry-feed install-fed situations. The importance and availability of fodder trees in tropical Africa are influenced by a number of factors such as the natural distribution of trees with in the agroecological zones, the distribution, types and importance of livestock and their integration and role within the farming system and the availability of alternative sources of fodder for livestock in the agroecological zones [29]. Leguminous pants are characterized by their ability to fix nitrogen and hence expected to improve soil fertility [30] that could be beneficial to companion plats while serving as a shade.

\section{Effect of different variables on Ficus thonningii ownership}

The effect of socioeconomic variables on the $F$. thonningii ownership of respondents is indicated in Table 4. The result revealed that in all areas and respondents, the ownership of $F$. thonningii tree was not affected by age, education level, family size and number of animals among study districts. This might be due to the fact that all 
respondents use $F$. thonningii tree without applying much input to improve the feeding value of the tree leaves. For all study districts, shortage of feed during the dry season was the major problem, and hence, more extension work should be done to create awareness on the planting and utilization of valuable fodders like $F$. thonningii $[31,32]$.

The planting method of $F$. thonningii in the districts was propagation method mainly in from May to June. The current status of $F$. thonningii according to all respondents $(100 \%)$ is become decreasing; however, the plant has many roles in the household. The reason might be due to expansion of crop land and lack of awareness on the management the tree. Multipurpose species of plants are known to have very important characteristics for tropical countries as these plants are resistant to drought and poor soil fertility as well as suitable for cut-and-carry feeding of livestock [33]. The finding is in agreement with earlier works in Ethiopia [5, 32].

\section{Animals fed Ficus thonningii}

The types of animals fed $F$. thonningii in the study districts are shown in Fig. 1. According to respondents, the types of animals fed the plant were cattle (54.2\%), sheep $(24.1 \%)$ and goats $(21.7 \%)$. But the majority of respondents provided to all animals in all districts as shown in Fig. 2. The parts of plant fed to animals in the study districts were leaf only in all respondents $(100 \%)$ in Bahir Dar Zuria districts, and 49\% leaf, 51\% leaf and twig in Farta district and both leaf and twig (100\%) in South Achefer district.

The $F$. thonningii tree has been considered very important in terms of palatability by diverse species of animals in Ethiopia. This can be taken as a very good indicator of its potential nutritive values and biomass yield $[34,35]$ and can replace the expensive concentrate mixes. Moreover, the tree has fast growth rate and easy propagation as indicated by [31].

\section{Form of feeding $F$. thonningii}

The form of feeding $F$. thonningii in study districts was in the form fresh and wilt. The respondent who feeds fresh and wilt is shown in Fig. 3. All respondents in study districts did not do processing on the ficus leaves and twigs which may be associated with lack of knowledge. The study revealed that feed shortage was major problem during dry season and as a result browse trees like $F$. thonningii are very important in the study area. All of the respondents feed leaves of $F$. thonningii to their livestock during dry season when other feeds are not available which is in agreement with the findings of [32] for different fodder sources. The result is also in agreement with [36] for Millettia ferruginea plant.
Except F. thonningii, other browse trees were less abundant during dry season in the study areas. The leaves of $F$. thonningii were supplemented to cattle and sheep as fresh bases in the study areas. The study is in agreement with the result of [37] who reported that leaves of the plant are important feeds of different livestock and can be very good source of nutrients during dry season. The result is in agreement with the previous reports in different parts of the country [38, 39]. Utilization of browse trees including other Ficus species for animal fodder was also reported in Ethiopia [5].

\section{Constraints related to $F$. thonningii production and utilization}

The major constraints related to $F$. thonningii production and utilization in study districts are shown in Fig. 4. The major constraint of $F$. thonningii production and utilization in the study district is lack of knowledge in the management and importance of the plant and in accessibility of harvesting of tree leaves which requires substantial technologies to properly harvest the fodder.

With regard to livestock feeding, there was no problem reported by all respondents (100\%) in Bahir Dar Zuria and Farta districts. However, 23\% of respondents in South Achefer district reported that animals faced coughing and bloating when fed $F$. thonningii leaves. Status of F. thonningii is decreasing according to key informants due to lack of awareness of management and utilization of $F$. thonningii. Generally, even though farmers in the study area have their own grazing land, the amount of feed was not adequate for the stock and they are forced to purchase feed resource from market like local breweries by-products (locally called atela) and traditional oil seed by-products known as noug seed cake. As to the amount of feeding of $F$. thonningii, most farmers gave feeds for their cattle by estimation without deciding the amount, body weight production level and the types of animals.

\section{Limitation of the study}

The limitation of the study is the methods of data collections used (focused on individual views). Hence, future research is recommended using recent techniques of data collection such as Theory of Planned Behavior and field counting of trees and measurement of fodder production potential of $F$. thonningii.

\section{Conclusion and recommendation}

Ficus thonningii is used for almost all types of ruminants to complement nutrient scarcity in the areas. However, lack of knowledge and scarcity of land affect its utilization in the studied districts. Hence, extension works should be strengthening the management and utilization of indigenous fodder trees, particularly Ficus thonningii 


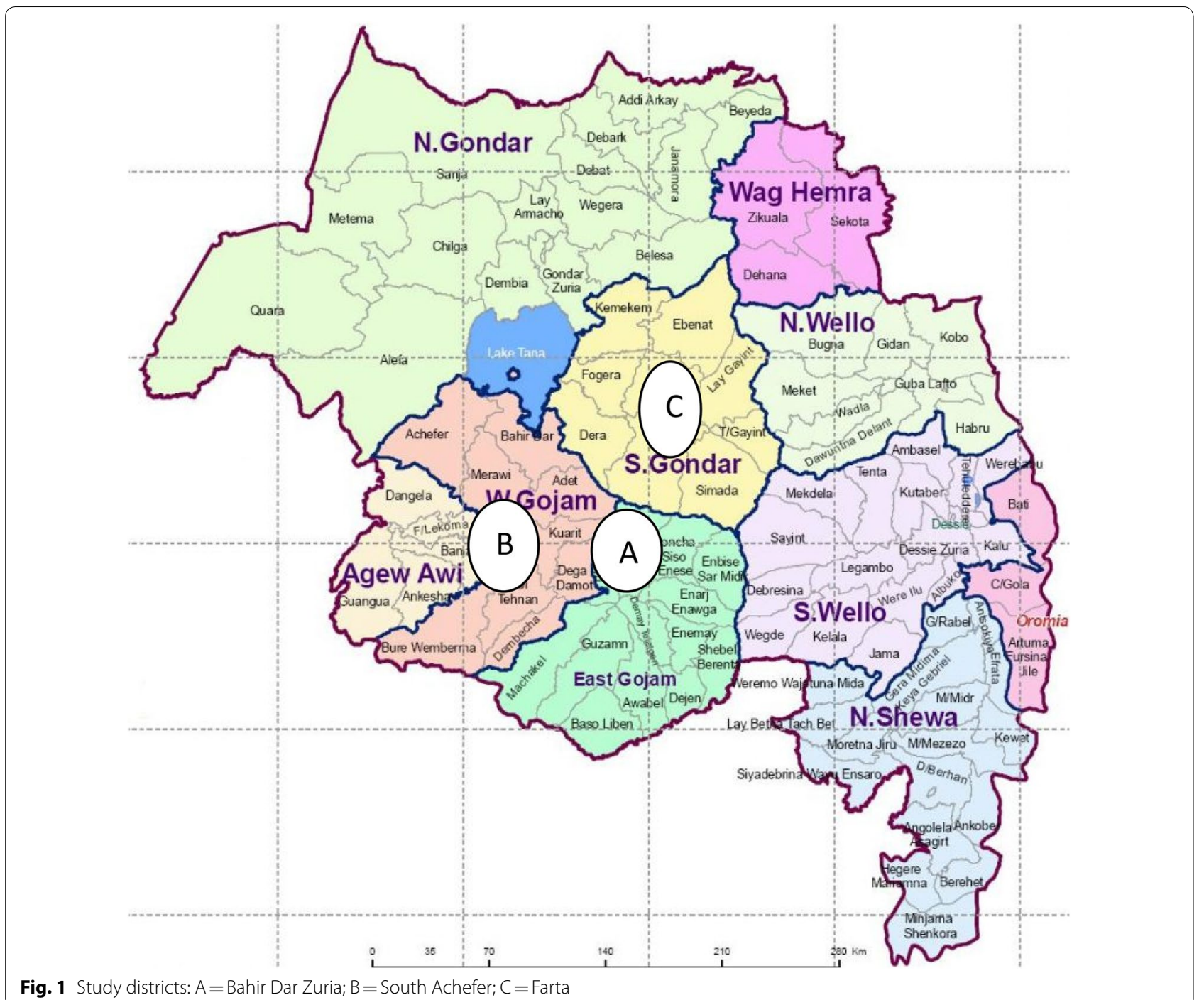

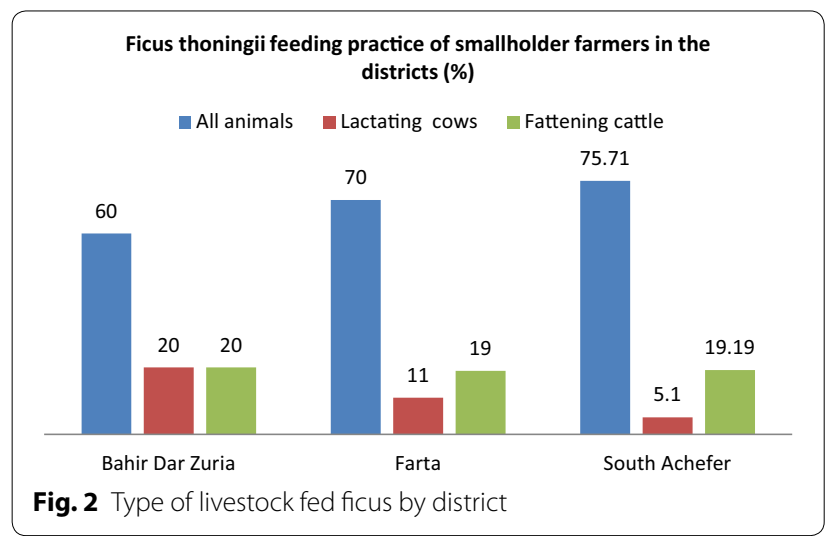

in the studied areas. Moreover, as harvesting was mentioned in the utilization of the ficus tree, it is important to devise a mechanism to tackle the problem. Further

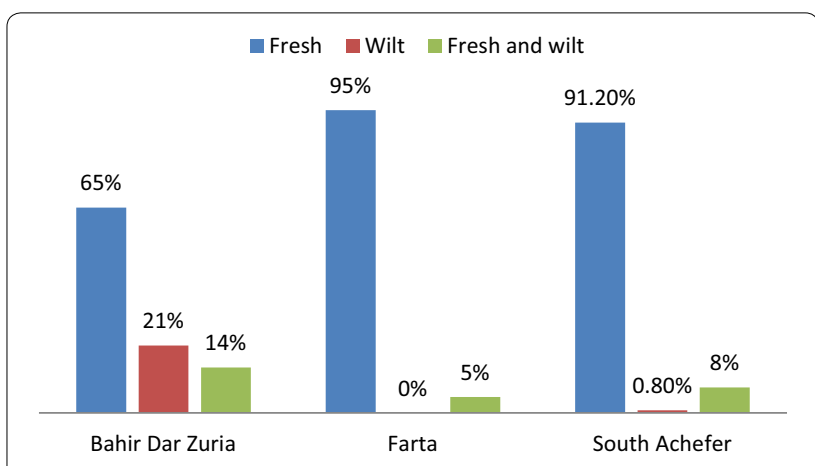

Fig. 3 Form of $F$. thonningii leaves feeding by respondents by districts

research on collection of the plant, adaptation agronomic study and animal evaluation of $F$. thonningii should be conducted. 


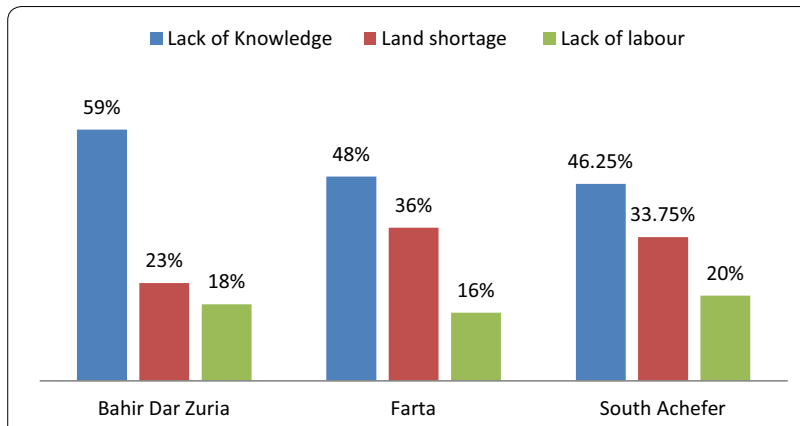

Fig. 4 Constraints of F. thonningii production and utilization

\section{Abbreviations}

BZD: Bahir Dar Zuria District; FD: Farta district; SAD: South Achefer District; HH: household head.

\section{Authors' contributions}

BA contributed in research proposal writing, data collection, data analysis, data interpretation and article writing. YM contributed in research data collection, data analysis, data interpretation and article writing. All authors read and approved the final manuscript.

\section{Authors' information}

Bimrew is an Assistant Professor of Animal Nutrition, currently teaching and conducting research in the area of animal feeds and feeding, animal production and productivity improvement in Ethiopia. Yeshambel is an Associate Professor of Animal Nutrition currently teaching and conducting research in animal production and productivity improvement in Ethiopia.

\section{Acknowledgements}

The authors would like to acknowledge farmers who participated in interview and group discussion, the office of Agriculture of respective districts for secondary data sources. We are also grateful to Getahun Ewnetu who helped us during data collection at field level.

\section{Competing interests}

The authors declare that they have no competing interests.

\section{Consent for publication}

Not applicable.

\section{Availability of supporting data}

The datasets are used and/or analyzed during the current study available from the corresponding author on request.

\section{Ethics approval and consent to participate}

Not applicable.

\section{Funding}

Not applicable.

\section{Publisher's Note}

Springer Nature remains neutral with regard to jurisdictional claims in published maps and institutional affiliations.

Received: 14 November 2018 Accepted: 21 December 2018

Published online: 16 January 2019

\section{References}

1. IGAD (Intergovernmental Authority on Development). The contribution of livestock to the economies of IGAD member states. IGAD LPI working paper No. 02-11. 2010.

2. Shapiro BI, Gebru G, Desta S, Negassa A, Nigussie K, Aboset G, Mechal H. Ethiopia livestock master plan. ILRI project report. Nairobi, Kenya: International Livestock Research Institute (ILRI). 2015.

3. CSA (Central Statistics Agency). sampling survey report on livestock and livestock characteristics (private peasant holdings). Stat Bull. 2017; 585:1-50

4. MacDonald M, Simon J. Climate, food security and growth: Ethiopia's complex relationship with livestock. Brighter Green, New York, p. 3-77. 2011. http://www.brightgreen-org/files/Ethiopia_bg_pp_2011.pdf.

5. Aregawi T, Melaku S, Nigatu L. Management and Utilization of browse species as livestock feed in semi-arid district of northwest Ethiopia. Livest Res Rural Dev. 2008;20(6).

6. Jokthan GE, Afikwu EV, Olugbemi TS. The utilization of Fig (F. thonningii) and Mango (Mangifera indica) leaves by rabbits. Department of Animal Science, Ahmadu Bello University, and Zaria, Nigeria. J Nutr. 2003;2(4):264-6.

7. HarvestChoice. Total livestock population (TLU) (2005). International Food Policy Research Institute, Washington, DC, and University of Minnesota, St. Paul, MN. 2011. http://harvestchoice.org/node/4788.

8. Belay D, Azage T, Hegde BP. Smallholder livestock production system in Dandi District, Oromia Regional State. Central Ethiopia. Glob Vet. 2012;8(5):472-9.

9. Belay H, Dagnew Z, Abebe N. Small scale water treatment practice and associated factors at Burie Zuria Woreda Rural Households, Northwest Ethiopia, 2015: cross sectional study. BMC Pub Health. 2016;16:887. https ://doi.org/10.1186/s12889-016-3571-2.

10. Amogne A, Belay S, Hassen A, Bantider A. Determinants of non-farm livelihood diversification: evidence from rainfed-dependent smallholder farmers in North central Ethiopia (Woleka sub-basin). Dev Stud Res. 2017:4(1):1-8

11. Jemal A, Kahssay M, Gebremedhin M. Household food insecurity, underweight status, and associated characteristics among women of reproductive age group in Assayita District, Afar Regional State, Ethiopia. J Environ Pub Health. 2018;2018:8. Article ID 7659204. https://doi. org/10.1155/2018/7659204.

12. Mekuriaw $Y$, Urge $M$, Animut $G$. Role of indigenous Bamboo species (Yushania alpina and Oxytenanthera abyssinica) as ruminant feed in northwestern Ethiopia. Livestock Research for Rural Development, vol. 23 , Article \#185. 2011.

13. Asmare B, Demeke S, Tolemariam T, Tegegne T, Wamatu J, Rischkowsky B. Determinants of the utilization of desho grass (Pennisetum pedicellatum) by farmers in Ethiopia. Trop Grassl (Trop Grassl Soc Aust). 2016;4(2):112-21.

14. Sisay A. Qualitative and quantitative aspects of animal feed in different agro ecological area of north Gonder. M.Sc. thesis. Alemaya University, Dire Dawa. 2006.

15. Mulugeta A. Characterization of dairy production systems of Yerer watershed in Ada Liben Wereda, Oromia Region, Ethiopia. An M.Sc. thesis presented to the School of Graduate Studies of Alemaya University, Alemaya University. 2005.

16. Getachew M, Tsehay R, Zelalem L, Gerba L, Duncan AJ, Yeshambel M. Assessment of livestock production systems, the potential of feed availability, farming system and livestock production problems in Fogera District, Amhara Region, Ethiopia (ILRI working document). 2015.

17. Atinkut Haimanot B, Bedri Abdulhamid K, Sentayehu Assefa K, Warren Dick. Farmers' investment on sustainable agricultural practices: evidence from Amhara Region, Ethiopia. Am J Life Sci. 2017;5(2):38-45.

18. Ojiako Ifeanyi A, Tarawali G, Okechukwu RU, Chianu JN. Household characteristics and market participation competence of smallholder farmers supplying cassava to starch processors in Nigeria. Int J Agric Res Innov Technol. 2016;6(2):42-56.

19. FAO (Food and Agriculture Organization of the United Nations). Country report. Addis Ababa: FAO; 2008.

20. Zinash S, Seyoum B. Utilization of feed resources and feeding systems in the central zone of Ethiopia. In: Proceedings of the third national livestock improvement conference. 24-26 May 1989. Addis Ababa, Ethiopia. p. 129-32. 1989. 
21. ARC (Agricultural Research Council). The nutrient requirements of ruminant livestock. Slough: Farnham Royal: Commonwealth Agricultural Bureaux; 1980.

22. Yayeh Z, Hailemariam M, Belhu K, Asmare B. Characterization of dairy cattle production systems in Debremarkos district, Amhara Regional State, Ethiopia. Pacesetter J. Agric. Sci. Res. 2014;2(1):42-54.

23. Mekuriaw $Y$, Asmare B. Assessment of pig production and constraints in Mecha district, Amhara Region. Northwestern Ethiopia. Adv Agric. 2014:2014:329254. https://doi.org/10.1155/2014/329254.

24. Lemma G. Crude protein and mineral status of forages grown on Pellic Vertisols of Ginchi, Central Highlands of Ethiopian. Ph.D. thesis. University of Sree State Bloemfontein. 2002.

25. Seyoum B, Getenet A, Abate T, Fekadu D. Present Status and future direction in feed resources and nutrition research targeted for wheat based crop livestock production system in Ethiopia. In: Wall PC, editor. Wheat and weed: food and feed. Proceedings of two-stakeholder workshop. CIMMYT, Mexico City. Improving the productivity of crop livestock production in wheat based farming systems in Ethiopia, Addis Ababa. 10-11 Oct 2000. p. 207-26. 2001.

26. Alemayehu M. Feed resources in Ethiopia. A paper presented at a work shop on animal feed Resources for small scales livestock procedure. 11-15 Nov 2003. Nairobi, Kenya. 2003.

27. Abebe M, Oosting SJ, Fernandez-Rivera S, Van der Zijpp AJ. Multipurpose fodder trees in the Ethiopian highlands: farmers' preference and relationship of indigenous knowledge of feed value with laboratory indicators. Agric Syst. 2008;96:184-94.

28. Adugna T, Said AN. Assessment of feed resources in Welayta Sodo. Environ Agric Sci. 1994;14(1/2):69-87.

29. Nitis IM, Lama K, Sukanta W, Suaran M, Putras S. The concept and development of the three Stata forage system. In: Devendra C, editor. Shrubs and tree fodders for farm animals. Ottawa: International Development Research Center (IDRC); 2000. p. q2-q102.
30. Deb S, Arunachalam A, Das AK. Indigenous knowledge of Nyishi tribes on traditional agro-forestry systems. Indian J Tradit Knowl. 2009;8(1):44-6.

31. Mekoya A, Oosting SJ, Fernandez-Rivera S, Van der Zijpp AJ. Multipurpose fodder trees in the Ethiopian highlands: farmers' preference and relationship of indigenous knowledge of feed value with laboratory indicators. Agric Syst. 2008;96(1-3):184-94.

32. Assefa F, Animut G, Mekasha Y, Urge M. Assessment of the feeding potential and utilization of Erythrina burana and Casimiroa edulis in Eastern Harerghe zone of Ethiopia. Livest Res Rural Dev. 2014;26(5).

33. Fagg CW, Stewart JL. The value of Acacia and Prosopis in arid and semiarid environments. J Arid Environ. 1994;27:3-25.

34. Balehegn M, Eniang EA, Hassen A. Estimation of browse biomass of Ficus thonningii, an indigenous multipurpose fodder tree in northern Ethiopia. Afr J Range Forage Sci. 2012;29(1):25-30.

35. Berhe DH, Tanga AA. Nutritional evaluation of Ficus thonningii Blume leaves as ruminant livestock feed in the Ahferom district of Tigray. Ethiopia. Afr J Range Forage Sci. 2013;30(3):1-6.

36. Alemu B, Animut G, Tolera A. Millettia ferruginea: An endemic legume tree as forage for ruminants in southern and northwestern Ethiopia. Livestock Research for Rural Development, vol. 25, Article \#44. 2013. Retrieved 31 Oct 2018, from http://www.Irrd.org//rrd25/3/alem25044.htm.

37. Balehegn M, Hintsa K. Effect of maturity on chemical composition of edible parts of Ficus thonningii Blume (Moraceae): an indigenous multipurpose fodder tree in Ethiopia. Livestock Research for Rural Development, vol. 27, Article \#233. 2015. Retrieved 31 Oct 2018, from http://www Irrd.org/lrrd27/12/bale27233.htm.

38. Teferi A. Identification and nutritional characterization of major browse species in Abergelle district of Tigray, Ethiopia. M.Sc. thesis, Alemaya University, Alemaya, Ethiopia. Alemaya, Ethiopia. 2006.

39. Gemeda B, Hassen A, Assafa T, Amen N, Ebro A. Identification and nutritive value of potential fodder trees and shrubs in the mid rift valley of Ethiopia. J Anim Plant Sci. 2012;22(4):1126-32.
Ready to submit your research? Choose BMC and benefit from:

- fast, convenient online submission

- thorough peer review by experienced researchers in your field

- rapid publication on acceptance

- support for research data, including large and complex data types

- gold Open Access which fosters wider collaboration and increased citations

- maximum visibility for your research: over 100M website views per year

At BMC, research is always in progress.

Learn more biomedcentral.com/submissions 